\title{
Association between Human Resource Management Practices and Organisational Citizenship Behaviour in Nepalese Commercial Banks
}

\author{
Rashmi Subedi, \\ Freelance Researcher, \\ Kathmandu, Nepal.
}

\author{
Dr. Arhan Sthapit, \\ Professor, \\ Faculty of Management \& Law, \\ Nepal Open University, \\ Kathmandu, Nepal.
}

(Received December 20, 2019; Accepted January 29, 2020)

\begin{abstract}
The study examines the association between HRM practices and organisational citizenship behaviour (OCB) in Nepalese commercial banks. Quantitative in nature, the study is based on a questionnaire survey method administered on 360 employees sampled from 9 commercial banks: both private and foreign joint venture banks. The OCB level - measured by dimensions of helping behaviour, courtesy and sportsmanship - among the bank employees was found to be at moderate level. No significant variation was found between overall OCBs of managers of both foreign joint venture and private commercial banks. OCB was found to have significant association with the bank employees' ethnicity and length of service, but no association with their gender. The studied HR practices of organisational climate and HR training and development have significantly positive relationship with $O C B$, while employee empowerment has negative impact on OCB. Out of four HR practices considered for the study, HR training and development was found to be the strongest predictor of $O C B$.
\end{abstract}

Keywords: Human resource management practices, organisational citizenship behaviour.

\section{INTRODUCTION:}

\section{Background:}

Organisational citizenship behaviour (OCB) is described as behaviours that go beyond the basic requirement of the job, which is, to large extent, flexible and is of benefit to the organisation. By flexible behaviour, it is meant that the behaviour is not an enforceable requirement of the role or the job description, that is, the clearly specifiable terms of the person's employment contract with the organisation; the behaviour is rather a matter of personal choice (Jain \& Jain, 2014).

OCB has been a key construct in the psychology and organisation management domains. It has received a huge deal of interest in the literature (Swarninathan \& Jawahar, 2013; Marshall, Moncrief, Lassk, \& Shepherd, 2012). Current research shows that not only in-role, but also extra-role behaviourorganisational citizenship behaviour — are essential in employee performance. The knowledge of organisational citizenship behaviour is also important for an organisation to survive. Several researchers found that employee satisfaction, organisational commitment, high performance human resource practices and motivation all impact and affect organisational citizenship behaviour (Swarninathan \& Jawahar, 2013). In explaining their study-results carried out among school teachers in Dhading district of Nepal, (Shrestha and Subedi 2020 Jan-Feb) observed that the prosperous social capital would also ensure the high OCB and 
it would remain visible in the form of good relationship, behaviour, sympathy and friendship towards coworkers; performing dedication and voluntary work; holding responsibilities and extra-work in schools. And, the high level of OCB would enthuse the people to exhibit their high performance, commitment, satisfaction, stability and effectiveness in their jobs (Shrestha \& Subedi, 2020 Jan-Feb)

On the other hand, HRM is assumed to affect knowledge, skills, abilities (Schuler \& Jackson, 1995), attitudes and behaviour of employees (Guest, 1997), and may therefore affect the performance of an organisation (Den Hartog, Boselie, \& Paauwe, 2004). The alignment of HRM with the organisation strategy (strategic fit) and the alignment of the various HRM practices, such as career opportunities, training and appraisal, within the organisation (internal fit) (Baron \& Kreps, 1999) are assumed to be important factors in explaining the link between HRM and organisational performance.

\section{Statement of the problem:}

As OCB is the new emerging dimension in an organisation, and has largely been considered as a positive behaviour that benefits the organisation in many ways. The prevalent interest in organisational citizenship behaviour stems primarily from the belief that such behaviours enhance organisational effectiveness. In Nepalese context, very few researches have been done on this topic and the organisation are now realising the importance of organisational citizenship behaviour in an organisation and how are these behaviours are being affected by the HR practices.

Thus, the purpose of this study is to examine the relationship between the selected HR practices and organisational citizenship behaviour in Nepalese banks. This study aims to investigate how human resources practices, such as employee training, organisational climate, employee empowerment and performance appraisal, affect OCBs, as well as raise the question to find out the existence of organisation citizenship behaviours as regards to helping behaviour, courtesy, and sportsmanship among the mangers of selected banks. Besides this, the research also aims to examine whether any significant difference exists between the OCB of employees of private commercial banks and foreign joint venture commercial banks in Nepal.

\section{Research objectives:}

The general objective of this study is to identify the relationship between HRM practices and organisational citizenship behaviour in Nepalese organisations. To achieve the general objective, the following specific objectives have been formulated:

- To analyse the general aspects of organisational citizenship behaviour (OCB) in context of Nepalese commercial banks; and

- To examine the impact of human resource practices on organisational citizenship behaviour (OCB) in Nepalese commercial banks

\section{LITERATURE REVIEW:}

The key variables under the study have been discussed in this Section.

\section{Organisational citizenship behaviour and HR Practices:}

OCB is an extension of pro-social behavioural studies undertaken in the 1970s (Organ, 1997) with an emphasis on altruistic behaviours in an organisational setting that incorporated spontaneity towards another party without an apparent prospect of extrinsic reward (Organ, Podsakosff, \& MacKenzie, 2006). Research shows that OCB can have a positive impact on organisational success through improvements in productivity, resource utilisation, group activity coordination, performance stability, employee recruitment, selection and retention, and the ability to adapt to environmental changes (Podsakoff, MacKenzie, Paine, \& Bachrach, 2000). Organ (1988) identified five dimensions of OCB: conscientiousness, sportsmanship, civic virtue, courtesy, and altruism. These five dimensions cover such organisational behaviours as helping co-workers, following company rules, not complaining, and actively participating in organisational affairs. Maharjan (2014) identified five factors affecting the organisational citizenship behaviour concerning university teachers in Nepal; namely; Job Satisfaction, Job Stress, Organisational Justice, Leadership Supports, and Organisational Commitment. Of the five factors, the study - through a regression analysis discovered a statistically significant impact of only two factors, viz., Job Stress and Organisational 
Commitment, on OCB of Nepalese University teachers, as the Working Environment moderated - with the statistical significance - the relationship between OCB and job satisfaction of Nepalese University teachers. However, association of HR practices with OCB is beyond the scope of the reviewed work.

Likewise, like Maharjan (2014), Jena and Goswami (2014) found a moderate level of influence of job satisfaction on OCB in a study carried out in the Indian state of Odissa. Therefore, job satisfaction has been identified as one of the predictors of OCB in this present study.

Pearce and Herbik (2004) investigated the effect of HR practices on Organisational Citizenship Behaviour in teams and how this relation is moderated by elements of leadership. Appelbaum conceptualised HR practices using the AMO model. Separate hypothesis was formulated for each of the elements of the model (Ability, Motivation and Opportunity). Based on the results only the hypothesis about the moderating effect of leadership on the relation between HR practices that enhance employees' Opportunity and Organisational Citizenship Behaviour is confirmed. Results of the regression analysis indicate, against expectations, that there is a negative relation between HR practices that enhance employees' Opportunity to participate as reported by the team leader and OCB. The finding also reveals the appealing possibility that this relation is mediated by perceptions of HR as experienced by the team. The relation in turn between perceptions of HR by the team and OCB is found to be positive.

Wei, Han and Hsu (2010) investigated the relationship between high performance human resource (HR) practices and OCB outcomes variable from a cross-level perspective. It also identifies the mediating role of job satisfaction in the relationship between psychological climate and OCB. Eleven manufacturing plants in Taiwan were taken into consideration and total sample was 576 employees. Hierarchical linear modelling (HLM) was used to test the relationship between the relationships between high-performance HR practices at the plant level and employee attitudes and behaviours at the individual level of analysis. From the result, it is concluded that OCB can be explained by high-performance HR practices. To test this prediction, control variables and two individual-level antecedents of OCB were entered as level one predictors, and highperformance HR practices were added to test. The results showed that high-performance HR practices are not significantly related to OCB.

Jain and Jain (2014) measured OCB of bank managers about their helping behaviour, courtesy and sportsmanship and the impact of HR practices such as organisational climate, employee training, employee empowerment and performance appraisal on OCB. Correlation analysis indicated that there is high or moderate degree of positive correlation exist between the study variable. All the HR practices are significantly and positively related, and have positive and significant impact on OCB. Similarly, from the multiple regression analysis it is concluded that independent variables explain the significant amount of variation in OCB. Among the HR practices, selected Employee Empowerment was found to be the strongest predictor of OCB, which is supported by the previous research.

Ahmed (2016) explored individual and joint effect of human resource management (HRM) practices on organisational citizenship behaviour (OCB) among Sudanese banking employees. This study's findings confirm the validity of the relationships between variables. The relationship between various HRM practices and OCB was investigated using correlation analysis while multiple regression analysis was used to find out the joint effect of various HRM practices against OCB. From the findings it is concluded that recruitment and selection (RSP) is significantly correlated to the OCB, training and development program (TDP) and OCB are of moderate positive relationship, compensation (CSR) have small but definite positive relationship with OCB. The results show CRS to be of least correlation and low significant value with OCB. Furthermore, there is positive significant correlation among performance appraisal system (PAS) and OCB, which supports the past studies. Result of multiple linear regression is adequate and significant. Overall, PAS is the most crucial HR practices for OCB, followed by RSP. In contrast, TDP and CRS are found to be not significant in predicting OCB in banking industry, PAS being the most crucial HR practices for OCB, had been supported by several studies. Lastly, multiple regression analysis result shows CRS and OCB is of insignificant relationship as CRS contribute only slight or almost no effect against OCB that also supports the past studies.

Keplinger, Kowal and Mäkiö (2016) examined the effect of gender and country (cultural and organisational differences) on the organisational citizenship behaviour (OCB) of information technology (IT) users in Poland (transition economy) and Germany (developed economy). The writer investigated two dimensions of human capital: the OCB individually oriented (OCBI) and organisationally oriented (OCBO). The online 
random survey comprised 280 Polish respondents and 72 German respondents, in different regions of the two countries. Findings show that effects of gender and country between Poland and Germany exist. In Germany, employees more appreciate OCB than in Poland. However, in both countries female subordinates had better evaluated supervisors' OCB than male subordinates would. Female supervisors evaluate worse subordinates' OCB than male supervisors.

A study by (Nguyen et al 2016) provides a closer look at the HR-OCB relationship in Taiwan. To examine the relationships between HR practices; recruitment and placement (RP), teaching, education and career (TEC) development, support communication and retention (SCR) and performance and appraisal (PA) and organisational commitment and citizenship behaviour at primary schools in Taiwan was the main propose of this research. With the assistance from the school HR managers and using anti-common variance strategy, research data from 568 incumbent teachers in Taiwan were collected and analysed. Based on the findings, HR practices may not necessarily contribute to citizenship behaviour. Teachers with positive perceptions of retention and placement and teaching, education and career were more likely to demonstrate citizenship behaviour, whereas teachers with positive perceptions of support, communication and retention and performance and appraisal were not. In addition to that, the study also found the three moderators; affective organisational commitment (AOC), rank of positions and campus size.

Harsasi, Muzammil and Radeswandri (2017) analysed the effects of HRM practices on OCB that is mediated by organisational commitment conducted at a higher distance education institution in Indonesia. The data were analysed using confirmatory factor analysis, Cronbach's Alpha, and path analysis. From the result of the path analysis, it was found a positive effect of the implementation of HRM on OCB, with organisational commitment as the mediating variable.

Jain and Jain (2017) examined the relationship between organisational investments in employee development and the resultant employee behaviour. A conceptual framework of inter-linkage between HRD climate, HRD systems and OCB was developed. The validity of the scales developed for the purpose of study was tested through the confirmatory factor analysis and the scales were found valid. The model was tested using structural equation modelling (SEM) on a sample of 306 bank managers in India. It is validated that HRD climate, performance appraisal, employee empowerment and employee training have broadbased influence on citizenship behaviour of the employees.

Misra (2018) studied the role of high-performance work systems as a set of workplace practices that enhance employee productivity and organisational performance. Using foundational research from the high-performance paradigm, the paper examines the effects of team-level strategic HR practices on job satisfaction. The paper also explores the benefits of participation in high performance work teams for employees working as part of these teams, owing to the closely-knit work outcomes and social networks that may develop among members. The study discovered that while high performance work practices may benefit employers, as they would increase organisational performance, they may do so at the cost of employee satisfaction as they could possibly push employees to work harder to raise productivity.

Drawing on the social exchange theory, (Bodla, Tang, van Dick and Mir July 2019) studied how authoritarian leadership influences employee OCB and found a curvilinear relationship between Organisational citizenship behaviour towards one's supervisor (OCBS) and authoritarian leadership being moderated by benevolent climate in Pakistani organisations. However, the paper placed its focus not on HR practices, but exclusively on authoritarian leadership, as far as OCB towards the supervisor as the criterion variable is concerned.

\section{Conceptual framework:}

Based on review of literature from different perspectives, the present researchers developed a theoretical framework of study to conduct similar research to fill the information gap prevalent in Nepalese context. The dependent variable for this study is the organisational citizenship behaviour prevailing in the Nepalese banks. Organisation citizenship behaviour has been defined into three dimensions; Helping behaviour, Courtesy and Sportsmanship. These dimensions are measured in three levels: low, moderate and high. 
Fig. 1.2: The conceptual framework

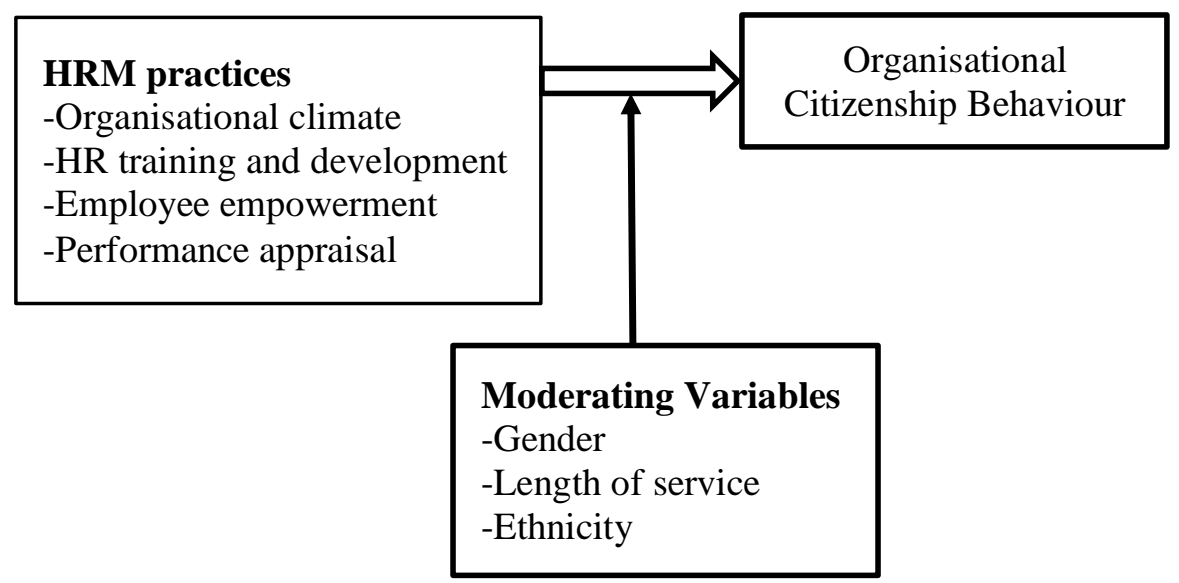

The study has identified as the independent variables the HRM practices affecting the organisational citizenship behaviour; namely, such as organisational climate, employee training, and employee empowerment and performance appraisal. For this study, gender and length of service of the employees are the moderating variables, which tend to affect the organisational citizenship behaviour.

\section{Research hypotheses:}

Dypothesis 1: The organisational citizenship behaviours as regard to helping behaviour, courtesy and sportsmanship exist favourably among managers in the selected banks.

> Hypothesis 2: There is no significant difference between the OCB of employees belonging to private commercial banks and foreign joint venture commercial banks in Nepal.

> Hypothesis 3: Organisational climate has positive and significant impact on organisational citizenship behaviour.

Hypothesis 4: Employee training and development (ETD) has positive and significant impact on the organisational citizenship behaviour.

$>$ Hypothesis 5: Employee empowerment (EE) has positive and significant impact on the organisational citizenship behaviour.

Hypothesis 6: Performance appraisal system (PAS) has positive and significant on the organisational citizenship behaviour.

\section{RESEARCH METHODS:}

The study adopted quantitative research methodology for a number of reasons. Firstly, the research is concerned with describing constructs or variables under study and relationship between them. Secondly, it allowed for the accurate and objective measurement of constructs of HR practices and OCB, as they were perceived by a representative sample of target population. Thirdly, the research was guided by explicitly stated objective formulated at beginning of research process. Finally, it was considered more cost effective, time effective and convenient compared to qualitative method.

However, the study also incorporated certain part of qualitative methodology, because the combination of both qualitative and quantitative method has been proven more valuable. To get deeper insight about the research topic, few of the respondents were interviewed during the research process. The stores shared by those respondents had helped further to understand to the antecedent of HR practices and OCB.

\section{Research Design:}

The study is an explorative study, as no previous research in context of Nepalese commercial banks has been found. The objective of the study is to assess the impact of HR practices (employee training and development, organisational climate, employee empowerment and performance appraisal) in OCB. The study adopted descriptive and analytical research design. The descriptive portion involved 
statistical testing of the proposed hypothesis in order to establish relationship between dependent and independent variable.

\section{Population and Sample:}

The population for this study comprises of all the assistant and junior officer level employees who are working in banking sector. Assistant and junior officer level employees were selected as the research aims to explore the OCB among the grass-roots level of banks. The total number of assistant and junior officer level employees involved in banking sector was known. The research was based on the respondents from Kathmandu valley. Simple stratified random sampling was done to selected commercial banks within Kathmandu valley. Population sampling method discovered by (Yamane 1967) was used to predict the sample for the research. Based on this model sample was calculated using the following formula:

Where,

$$
\mathrm{n}=\frac{\mathrm{N}}{1+\mathrm{N}\left(\mathrm{e}^{2}\right)}
$$

$\mathrm{N}=$ Total population

$\mathrm{n}=$ Sample size

$\mathrm{e}=$ Level of precision

The total population was 3,600 , so the sample taken is 360 assistant and junior officer level employees. The survey questionnaires were distributed among 360 employees working in 9 different commercial banks; both private commercial bank and foreign joint venture commercial banks.

The private commercial banks and foreign joint venture commercial bank included in the study were selected on the basis the year of establishment. The private commercial bank established between the years 2005 to 2015 and the foreign joint venture commercial bank established before 1995 and which holds major foreign shareholders were selected.

The structured questionnaire that was designed as per the description in the article "Organisational Citizenship Behaviour and HRM Practices in Indian Banks" (Jain and Jain 2014) was divided into three sections. The first section included general introduction regarding the study and demographic variables (i.e., gender, age, education level, length of service, working department and the managerial level). The second section comprises of general questions regarding the dimension of OCB in an organisation. In addition, the third section includes the dimension of HRM Practices. The survey was conducted using the five-point Likert type scale.

OCB was measured using the seventeen-item scale that measures the three dimensions of OCB. The helping behaviour subscale was adopted from the scales developed by (Podsakoff, MacKenzie, Moorman and Fetter 1990; Rego 1999), six items: courtesy sub-scale which was taken from the scale posited by (Podsakoff and MacKenzie 1997); six items sportsmanship sub-scale was adopted from the scale developed by (Rego 1999). Organisational Climate and Employee Training and Development that was measured with the administration scale partially adopted from HRD questionnaire developed by (Jain \& Jain, 2014). Employee empowerment was measured using twelve-item scale developed by (Riggs, Warka, Betancourt and Hooker 1994). Finally, performance appraisal was measured with seven-item scale, which was developed as per the relevancy of Nepalese context.

\section{Reliability and Validity:}

The reliability of item scale is tested by computation of Cronbach's alpha. In this study, Cronbach's alpha is calculated to measure the reliability of the item scales such as helping behaviour, courtesy, sportsmanship, HRD climate, employee training, employee empowerment and performance appraisal. Cronbach's Alpha also helps to determine if there are single or multiple items that are needed to be removed from the scale to improve the reliability. Generally, a coefficient of at least 0.70 is considered as a good indication of construct reliability (Nunnally, 1978). 
Table 1 : Reliability statistics

\begin{tabular}{|l|c|c|}
\hline \multicolumn{1}{|c|}{ Variables } & No. of items & Cronbach's Alpha \\
\hline Helping behaviour & 5 & 0.743 \\
Courtesy & 4 & 0.700 \\
Sportsmanship & 6 & 0.788 \\
HRD climate & 6 & 0.778 \\
Employee Training & 6 & 0.733 \\
Employee Empowerment & 5 & 0.758 \\
Performance Appraisal & 6 & 0.785 \\
\hline Note: From authors' survey, 2018 & & \\
\hline
\end{tabular}

Table 1 illustrates the reliability statistics. The data presented show the Cronbach's alpha value for the constructs used in the study. The Cronbach's alpha for helping behaviour, courtesy, sportsmanship, HRD climate, employee training and development, employee empowerment, performance appraisal are 0.743 , $0.7,0.788,0.778,0.773,0.758$, and 0.785 respectively, which indicate an acceptable degree of reliability.

\section{Demographic Characteristics:}

This section explains the demographic characteristics of the respondents. In this section, the respondents profile has been analysed in terms of gender, age, education level, marital status, job experience and residency.

Table 2 : Demographic characteristics of respondents

\begin{tabular}{|c|c|c|c|}
\hline & Characteristics & Frequency & Percentage \\
\hline Gender & $\begin{array}{l}\text { Male } \\
\text { Female }\end{array}$ & $\begin{array}{l}144 \\
216\end{array}$ & $\begin{array}{l}40 \\
60\end{array}$ \\
\hline Age & $\begin{array}{l}\text { Below } 30 \\
30-39 \\
40-49\end{array}$ & $\begin{array}{c}288 \\
72 \\
0\end{array}$ & $\begin{array}{c}80 \\
20 \\
-\end{array}$ \\
\hline Birthplace & $\begin{array}{l}\text { Inside Kathmandu Valley } \\
\text { Outside Kathmandu Valley }\end{array}$ & $\begin{array}{l}243 \\
117\end{array}$ & $\begin{array}{l}67.5 \\
32.5\end{array}$ \\
\hline Education level & $\begin{array}{l}\text { Intermediate or plus } 2 \\
\text { Bachelors' degree } \\
\text { Masters' degree or above }\end{array}$ & $\begin{array}{c}89 \\
130 \\
141\end{array}$ & $\begin{array}{l}24.7 \\
36.1 \\
39.2\end{array}$ \\
\hline Marital status & $\begin{array}{l}\text { Single } \\
\text { Married } \\
\text { Others }\end{array}$ & $\begin{array}{c}216 \\
126 \\
18\end{array}$ & $\begin{array}{c}60 \\
35 \\
5\end{array}$ \\
\hline Job experience & $\begin{array}{l}\text { Below five years } \\
5 \text { years and above }\end{array}$ & $\begin{array}{l}198 \\
162\end{array}$ & $\begin{array}{l}55 \\
45\end{array}$ \\
\hline Designation/ Hierarchy & $\begin{array}{l}\text { Junior assistant } \\
\text { Management trainee } \\
\text { Junior officer }\end{array}$ & $\begin{array}{c}117 \\
52 \\
91\end{array}$ & $\begin{array}{l}45 \\
20 \\
35\end{array}$ \\
\hline Ethnicity & $\begin{array}{l}\text { Caste group } \\
\text { Indigenous groups and others }\end{array}$ & $\begin{array}{l}126 \\
234\end{array}$ & $\begin{array}{l}35 \\
65\end{array}$ \\
\hline
\end{tabular}




\section{LIMITATIONS OF THE STUDY:}

The study would suffer from the following limitations:

$>$ The study results cannot be generalised to employees from other organisation and state-owned banks as the population and sample of the study is restricted to the employees of selected nine non stateowned banks only.

Only limited analytical tools were used in examining the effect of HR practices on OCB.

As the study is focused on intentionality, intentions may not always turn into actual behaviours in the future.

\section{DATA AND RESULTS:}

To examine the association between the HR practices and OCB at commercial banks in Nepal, the data collected through a questionnaire survey have been analysed and the results presented in the following paragraphs.

\section{Dimensions of organisation citizenship behaviour:}

The organisational citizenship behaviours exist moderately among bank employees in Nepal as the study considered the three OCB dimensions, viz., helping behaviour, courtesy and sportsmanship, which all have mean values greater than 3 measured on the 5 -anchor Likert Scale data, Hence, $\mathrm{H}_{1}$ is accepted. And, Table 3 further shows that based on the mean value, bankers reported their helping behaviour (mean value 3.322) as the highest OCB dimension followed by sportsmanship (3.258).

Table 3 : Dimensions of OCB

\begin{tabular}{|c|l|c|c|c|c|}
\hline S.N & Characteristics & Mean & Rank & s.d & Level of OCB \\
\hline 1. & Helping Behaviour & 3.322 & 1 & 0.691 & Moderate \\
2. & Sportsmanship & 3.258 & 2 & 0.769 & Moderate \\
3. & Courtesy & 3.190 & 3 & 0.629 & Moderate \\
& Overall OCB & 3.225 & & 0.470 & Moderate \\
\hline
\end{tabular}

Note: Based on authors' survey, 2018

\section{Moderating effect of demographic factors on organisation citizenship behaviour:}

The study has taken stock of the moderating effect of such demographic factors as gender, ethnicity and length of service of the sample bank employees on their OCB and the data results have been presented in Table No. 4 .

In regard to the relationship between demographic factors and $\mathrm{OCB}$, the Chi-square test has shown that the employees' ethnicity ( $\mathrm{p}$-value $=0.000<0.001$ ) — categorised into caste (Brahmin and Kshatriya) and indigenous and other groups - has a significant effect on OCB. Likewise, length of service of the employees - categorised into below 5 years and 5 years and above - also reported existence of significant association with OCB ( $\mathrm{p}$-value $=0.000<0.001$ On the other hand, the bankers' gender ( $\mathrm{p}$-value $=0.309>0.005$ ) has no significant association with their OCB as presented in Table 2 .

Table 4 : Chi-square test between Gender of Employees and OCB

\begin{tabular}{|l|c|c|c|}
\hline & Value & df & Asymp. Sig. (2-sided) \\
\hline Chi-Square & $2.346^{\mathrm{a}}$ & 2 & .309 \\
\hline Likelihood Ratio & 2.358 & 2 & .308 \\
\hline Linear-by-Linear Association & 1.875 & 1 & .171 \\
\hline
\end{tabular}




\begin{tabular}{|l|c|c|c|}
\hline \multicolumn{4}{|c|}{ Chi-square test between Ethnicity of respondent and OCB } \\
\hline Chi-Square & $53.104^{\mathrm{a}}$ & 2 & .000 \\
\hline Likelihood Ratio & 57.295 & 2 & .000 \\
\hline Linear-by-Linear Association & 46.432 & 1 & .000 \\
\hline \multicolumn{2}{|c|}{ Chi-square test between Length of service of respondent and OCB } \\
\hline Chi-Square & $444.097^{\mathrm{a}}$ & 2 & .000 \\
\hline Likelihood Ratio & 44.884 & 2 & .000 \\
\hline Linear-by-Linear Association & 32.016 & 1 & .000 \\
\hline Note: Based on authors' survey, 2018 & \\
\hline
\end{tabular}

The findings imply that bank employees' ethnicity and length of service moderate their organisational citizenship behaviour dynamics vis-a-vis the HR practices, whereas their gender would not.

OCB dimensions by private bank sub-sectors:

The study was also interested in investigating into the variation between the two sub-sectors of private sector banks in Nepal, viz., foreign joint venture and private commercial banks for which an analysis of variance (ANOVA) test has been performed. From Table 5), it is evident that there is no significant variation between overall OCBs of employees of foreign joint venture and private commercial banks. With the pvalue figuring larger than 0.05 , the finding has rejected $\mathrm{H}_{2}$ establishing that foreign joint venture and private commercial banks would not vary by the overall OCB and its constituent dimensions of helping behaviour, courtesy and sportsmanship.

Table 5 : One-way ANOVA test

\begin{tabular}{|l|l|c|c|c|c|c|}
\hline \multicolumn{2}{|c}{ OCB dimensions } & Sum of Squares & df & Mean Square & F & Sig. \\
\hline \multirow{3}{*}{ Helping Behaviour } & Between Groups & .034 & 1 & .034 & .070 & .791 \\
\cline { 2 - 7 } & Within Groups & 171.433 & 358 & .479 & & \\
\hline \multirow{3}{*}{ Courtesy } & Between Groups & .105 & 1 & .105 & .273 & .602 \\
\cline { 2 - 7 } & Within Groups & 137.861 & 358 & .385 & & \\
\hline \multirow{3}{*}{ Sportsmanship } & Between Groups & .047 & 1 & .047 & .079 & .779 \\
\cline { 2 - 7 } & Within Groups & 212.675 & 358 & .594 & & \\
\hline \multirow{3}{*}{ Overall OCB } & Between Groups & .042 & 1 & .042 & .190 & .664 \\
\cline { 2 - 7 } & Within Groups & 78.658 & 358 & .220 & & \\
\hline
\end{tabular}

Note: Based on authors'survey, 2018

\section{Impact of HRM practices on OCB:}

The study is primarily interested in examining the association between the antecedents of HR practices and OCB and the impact of the former on the latter in the context of Nepalese organisations for which correlation and regression analyses on the data have been performed.

The data analysis as presented in Table 6 establishes that the antecedents of HR practices are statistically correlated with OCB in Nepalese banks. Specifically put, organisational climate, employee 
training and development, and performance appraisal system are positively correlated at 5 percent level of significance (on a two-tailed test) with OCB. However, employee empowerment has negative association with OCB; it may imply that the bank employees empowered by the organisation would digress from behaving like an organisational citizen.

Table 6 : Antecedents of HR practices and OCB: A correlation analysis

\begin{tabular}{|c|c|c|c|c|c|c|}
\hline \multirow{2}{*}{ Variables } & \multirow{2}{*}{$\begin{array}{c}\text { Mean } \\
\mathbf{N}=\mathbf{3 6 0}\end{array}$} & OCB & $\mathbf{O C}$ & ETD & $\mathbf{E E}$ & PAS \\
\hline & & 1 & 2 & 3 & 4 & 5 \\
\hline 1. OCB & 3.217 & 1 & & & & \\
\hline 2. Organisational climate (OC) & 3.251 & $.295 * *$ & 1 & & & \\
\hline 3. Employee training and development (ETD) & 3.128 & $.262 * *$ & $.514 *$ & 1 & & \\
\hline 4. Employee empowerment (EE) & 3.052 & $-.151 * *$ & $.447 * *$ & $.309 * *$ & 1 & \\
\hline 5. Performance appraisal system (PAS) & 3.185 & $.225 * *$ & $.109 *$ & $.169 * *$ & $-.033 * *$ & 1 \\
\hline \multicolumn{7}{|l|}{$\begin{array}{l}* \text {. Correlation significant at } 0.01 \text { level }(2 \text {-tailed }) \\
* * \text {. Correlation significant at } 0.05 \text { level }(2 \text {-tailed })\end{array}$} \\
\hline \multicolumn{7}{|l|}{ Note: Based on authors' survey, 2018} \\
\hline
\end{tabular}

According to the results presented in Table 6 , the correlation coefficients between the antecedents of HR practices have posted a statistically significant, positive association; except for that between performance appraisal system and employee empowerment; they have a statistically significant, negative correlation.

The findings from the correlation analysis posit that, as the organisation generates good outcomes from HR training and development, it results into an improved organisation climate which, in turn, contributes to the betterment of HR training and development system (coefficient $=.514$; sig at $1 \%$ ). Good outcomes from HR training and development also help empower employees (coefficient $=.309$; sig at $5 \%$ ) improve performance appraisal system (coefficient $=.169$; sig at $5 \%$ ) and vice versa.

Further, organisation climate is what a good performance appraisal system and employee empowerment can improve and vice versa; and the correlations between them (.447 and .109) have posted significance at $5 \%$ and $1 \%$, respectively. Therefore, the correlation coefficients between them being statistically significant have matched with the theoretical underpinnings.

However, performance appraisal system and employee empowerment have posted a negative correlation (.033 ), which is statistically significant at 5\%. It may be attributed to the possibility that the bank employees believed their employer's employee empowerment efforts are not matched with their performance appraisal system but they remain largely disassociated.

Further, since there is a significant correlation between HR practices and OCB as discussed earlier in Table 6 , it permits performing a regression analysis to examine the impact of the antecedents of HR practices (organisational climate, employee training and development, employee empowerment and performance appraisal system) on OCB. The results of linear regression analysis are presented in Table 4.5:

Table 7: Impact of HR practices on OCB (Regression analysis)

Model: $\mathrm{OCB}=\mathrm{a}+\beta_{1} \mathrm{OC}+\beta_{2} \mathrm{ET}+\beta_{3} \mathrm{EE}+\beta_{4} \mathrm{PA}+\mathrm{e} \ldots \ldots \ldots \ldots \ldots$ (i)

a. Dependent Variable: Organisational citizenship behaviour (OCB)

b. Predictors: (Constant), organisational climate, employee training and development, employee empowerment, and performance appraisal.

\begin{tabular}{|l|c|}
\hline Constant & 2.271 \\
& $(.000)$ \\
\hline Organisation climate & $.204^{*}$ \\
Employee training and development & $(.000)$ \\
\hline
\end{tabular}




\begin{tabular}{|l|c|}
\hline Employee empowerment & $\begin{array}{c}-.240^{*} \\
(.000)\end{array}$ \\
\hline Performance appraisal & $\begin{array}{c}.233^{*} \\
(.000)\end{array}$ \\
\hline $\mathrm{R}^{2}$ & .165 \\
\hline Adjusted $\mathrm{R}^{2}$ & .156 \\
\hline $\mathrm{F}$ & $\begin{array}{c}17.571 * \\
(.000)\end{array}$ \\
\hline $\begin{array}{l}\text { The numbers in the parentheses are the p-values. } \\
\text { *Significantly different from zero at the 0.01 level. } \\
\text { Note: Based on authors' survey, 2018 }\end{array}$ \\
\hline
\end{tabular}

Table 7 illustrates the regression results of OCB on the antecedents of HR practices. The F-value figuring 17.571 which is significant at 0.01 level indicates that the regression model fits with the data, when performing the regression of OCB on HR practices. It implies that the independent variables of antecedents of HR practices explain significant amount of variation in OCB.

The HR practices (organisational climate, employee training and development, employee empowerment and performance appraisal) explain the Organisation Citizenship Behaviour to the tune of 16.5 per cent. Likewise, in order to determine which independent variables significantly predict OCB, the value of t-test statistics has been analysed, and presented in Table 7. T-test value for organisational climate (OC) was calculated at 4.029 with beta value of .204 (p-value of .000<.005); it implies that organisational climate has positive and statistically significant impact on organisational citizenship behaviour in Nepalese banks. The value of beta is the degree of change in the outcome variable for every one-unit of change in the predictor variable. Since the beta value is positive it means that for every one-unit increase in the predictor variable, the outcome variable increases by beta value, i.e., by .204 in case of organisational climate; therefore, $\mathrm{H}_{3}$ is accepted.

Similarly, the values of t-statistics for employee training and development (ETD) is 4.536, with the beta value of .229 and the p-value is .000<.005; it shows that ETD has positive and statistically significant impact on $\mathrm{OCB}$; hence $\mathrm{H}_{4}$ is accepted.

On the other hand, the t-value for employee empowerment (EE) was found to be in negative, i.e., -4.698: its beta value is -.240; it indicates that it has negative but significant impact on OCB ( $<<.005)$. It does not support the theory as presented in the hypothesis. Since the beta value is negative in case of employee empowerment it means that for every one-unit change in the predictor variable, the outcome variable decreases by beta value, i.e., by 2.40 ; hence, $\mathrm{H}_{5}$ cannot be accepted.

And, in case of performance appraisal system, the t-value was calculated at 4.686, with the beta value .233, whose $\mathrm{p}$-value is $.000(\mathrm{p}<.005)$. Performance appraisal system (PAS), therefore, has positive and significant impact on OCB. Since the beta value is positive it means that for every one-unit increase in the PAS, the OCB increases by beta value of .233 ; hence, $\mathrm{H}_{6}$ is accepted.

As presented in Table 7, the largest beta coefficient $(\beta)$ is 0.233 belonging to the performance appraisal system. It means that performance appraisal system makes the strongest unique contribution to explain the OCB (dependent variable), when the variance explained by all the other predictors in the model are controlled for. The second strongest contribution comes from employee training and development $(\beta=.229)$ followed by organisational climate and employee empowerment. The regression results, therefore, reveal that the independent variables; organisational climate employee training and development and performance appraisal positively and significantly influence OCB, while employee empowerment influences OCB negatively with statistical significance.

\section{CONCLUSION AND IMPLICATIONS:}

All the OCB dimensions are found at moderate level in case of Nepalese commercial banks. Among the OCB dimensions, helping behaviour has the highest mean which implies that there exist high-level of helping behaviour among the employees of commercial bank. Similarly, sportsmanship also exists favourably among the employees based on the mean value. Among the three dimensions of OCB, courtesy was found to be least among the assistant level employees of commercial banks. 
Furthermore, among the HR practices, organisational climate has the highest mean which implies that it has more influence on the employees followed by performance appraisal and employee training, while employee empowerment has the lowest mean among the HR practices. In case of Nepal the implementation of HR practices has just started as many organisations yet are reluctant to implement the HR practices formally. The level of HR practices among the Nepalese organisation is found to be at moderate level. The study has assisted in validating prior findings by cracking light on the significance relationship between HR practices and OCB. It has confirmed that gender has no significant relationship with OCB of the respondent. While the other variables like ethnicity and length of service of the respondent has significant relationship with OCB. It implies that based on the ethnicity either it is indigenous or caste, the research has found out that the organisational citizenship behaviour is found to be different among caste and indigenous groups. Similarly, the length of service variable either it is less than 5 years or more than 5 years, the research has found that differences occurs on OCB based on the time period that the employees have worked in a commercial bank.

The impact of HR practices and OCB has been assisted by the findings. The antecedent of HR practices such as organisational climate, employee empowerment, performance appraisal has positive and significant impact with the OCB among the employees while employee empow erment has negative impact on OCB in case of Nepalese organisation. This study found a significant negative correlation between employee empowerment and OCB which implies that, in Nepalese banking sector when employees are more empowered their OCB level decreases which means that they would bring ineffective functioning in organisational performance emphasising the need for management at all levels to less empower employee. It should be noted that HR practices, such as maintaining open and clear channels of communication, not only enhance a feeling of trust but also give an employee a sense of control and participation.

This research highlights importance of various types of OCBs of employees of commercial banks. Utilising this knowledge, managers should encourage employees to consider a wide range of OCBs in their workplace. A number of prior studies (Wei et al., 2010; Pare \& Trembley, 2007) indicate positive HRMOCB relationship. However, earlier research studied dissimilar sets of HRM practices while analysing linkages with OCB. Further relational studies should include a broad range of HRM practices and other organisational processes while focusing on HRM-OCB relationship.

The current study only focused upon the direct effect that HRM practices have upon OCB; however, future research may focus on studying indirect linkages that particular HRM practices may share with OCB or particular dimensions of OCB. Further, empirical research studies may be done in future to assess the influence of HRM practices on organisational performance or effectiveness via OCB as a mediating variable. Similarly, future research may examine the potential mediators between HRM practices and Organisational Citizenship Behaviours. Thus, it can be said that the scope is wide open for future studies to explore the issues, which remain unaddressed but critically raised in the present study.

More areas of studies on OCB can be explored. For instance, organisational commitment and supervisory support may be valuable addition to the existing group of variables; as they impact both HR practices and overall OCB. Since the study is limited only to assistants and junior management level employees of commercial banks, future studies can be extended to cover employees belonging to other organisations and senior level employees that may provide deeper insights into the existing body of literature.

\section{REFERENCES:}

Ahmed, N. O. (2016). Impact of human resource management practices on organizational citizenship behavior: An empirical investigation from banking sector of Sudan, International Review of Management and Marketing, 6(4), 964-973.

Baron, J. N., \& Kreps, D. M. (1999). Strategic human resources. Frameworkfor general, New York: Wiley and sons.

Bodla, A.A., Tang, N., Van Dick, R., Mir, U.R. (July 2019). Authoritarian leadership, organizational citizenship behavior, and organizational deviance: Curvilinear relationships, Leadership \& Organization Development Journal, 40(5), 583-599. DOI: 10.1108/LODJ-08-2018-0313 
DenHartog, D. N., Boselie, P., \& Paauwe, J. (2004). Performance Management: A model and research agenda, Applied Psychology: An International Review, 53(4), 556-569.

Guest, D. E. (1997). Human resource management and performance: A Review and Research Agenda, International Journal of Human Resource Management, 8(3), 263-276.

Harsasi, M., Muzammil, M., \& Radeswandri (2017). The Effects of applying good human resources management practices on organizational citizenship behavior, Review of Integrative Business and Economics Research, 6(4), 196-213.

Jain, S., \& Jain, R. (2014). Organizational citizenship behavior \& HRM practices in Indian banks, Indian Journal of Industrial Relations, 50(2), 257-269.

Jain, S., \& Jain, R. (2017). HRD climate, HRD systems \& OCB: linkages conceptualization, measure \& model fit, The Indian Journal of Industrial Relations, 52(3), 484-498.

Jena, R.K., \& Goswami, K. (2014). Measuring the determinants of organizational citizenship behavior, Global Business Review, 15(2) 381-396. Sage, Retrieved from https://journals.sagepub.com/doi/ pdf/10.1177/0972150914523587

Keplinger, A., Kowal, J., \& Mäkiö, J. (2016). Gender and organizational citizenship behavior of information technology users in Poland and Germany, Academy of Management Journal, 23(3), 224-244.

Maharjan, S. (2014). Factors affecting organisational citizenship behaviour. (Unpublished Mini Research) submitted to University Grants Commission, Nepal (UGC/N).

Marshall, G., Moncrief, W. C., Lassk, F. G., \& Shepherd, C. D. (2012). Linking performance outcomes to salesperson organizational citizenship behaviour in an industrial sales setting, Journal of Personal Selling and Sales Management, 13(4), 491-501.

Misra, K. (2018). High-Performance human resource practices and team job satisfaction: Moderating role of team citizenship behaviors, International Journal of Human Resource Studies, 8(3), 86-102.

Nguyen, B., Chang, K., Cheng, K. T., Kuo, C. C., \& Lee, I. (2016). HR practice, organisational commitment $\&$ citizenship behaviour: A study of primary school teachers in Taiwan, Employee Relations, 38(6), 907-926.

Nunnally, J. C. (1978). Psychometric theory, New York: McGraw-Hill.

Organ, D. W. (1988). Organizational citizenship behavior: The good soldier syndrome, Lexington, MA: Lexington Books.

Organ, D. W. (1997). Organization citizenship behavior: It's construct clean-up time, Human Performance, 10(2), 85-97.

Organ, D. W., Podsakosff, P. M., \& MacKenzie, S. B. (2006). Organizational citizenship behavior. Thousand Oaks, California, USA: Sage.

Paré, G., \& Tremblay, M. (2007). The influence of high-involvement human resources practices, procedural justice, organizational commitment, and citizenship behaviors on information technology professionals' turnover intentions. Group \& Organization Management, 32(3), 326-357. https://doi.org/10.1177/1059601106286875

Pearce, C. L., \& Herbik, P. A. (2004). Citizenship behavior at the team level of analysis: The effects of team leadership, team commitment, perceived team support, and team size, The Journal of Social Psychology, 144(3), 293-310.

Podsakoff, P. M., M., A., \& MacKenzie, S. B. (1997). Organizational citizenship behaviour and the quantity and quality of work group performance, Journal of Applied Psychology, 82(2), 262-270.

Podsakoff, P. M., MacKenzie, S. B., Moorman, R. H., \& Fetter, K. (1990). Transformational leader behaviors and their effects on followers' trust in leader, satisfaction, and organizational citizenship behaviors, Leadership Quarterly, 1(1), 107-142.

Podsakoff, P. M., MacKenzie, S. B., Paine, J. B., \& Bachrach, D. G. (2000). Organizational citizenship behaviors: A critical review of the theoretical and empirical literature and suggestions for future research, Journal of Management, 26, 513-563.

Rego, A. (1999). Organizational citizenship behavior: operationalizing the construct, Psicologia, 127-148.

Riggs, M. L., Warka, J., Betancourt, R., \& Hooker, S. (1994). Development and validation of self-efficacy and outcome expectancy scales for job-related applications, Educational and Psychological Measurement, 793-802. 
Schuler, R. S., \& Jackson, S. E. (1995). Understanding human resource management in the context of organizations and their environment, Annual Review of Psychology, 46, 237-264.

Shrestha, M., \& Subedi, D. (2020 Jan-Feb). Organizational citizenship behavior among teachers of Nepal, American Journal of Economics and Business Management, 3(1), 1-23. Retrieved from https://www.academia.edu/41670679/Organizational_Citizenship_Behavior_among_Teachers_of _Nepal_Did_Locale_Contribute_it_s_in_School_Settings

Swarninathan, S., \& Jawahar, P. (2013). Job satisfaction as a predictor of organizational citizenship behaviour: an empirical study, Global Journal of Business Research, 7(1), 71-80.

Wei, Y.C., Han, T.S., \& Hsu, I.C. (2010). High-performance HR practices and OCB: A cross-level investigation of a causal path, The International Journal of Human Resource Management, 21(10), 1631-1648.

Yamane, T. (1967). Statistics: An introductory analysis (2nd ed.), New York: Harper \& Row

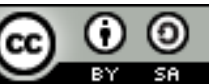

